\title{
ГЕНДЕРНІ ОСОБЛИВОСТІ РОЗВИТКУ ШВИДКОСТІ НА СПОРТИВНО- ОЗДОРОВЧОМУ ЕТАПІ ПІДГОТОВКИ В КІОКУШИНКАЙ КАРАТЕ
}

\author{
Микола Зимогляд ${ }^{1 \mathrm{ABCD}}$, Світлана Марченко ${ }^{1 \mathrm{ABCD}}$ \\ ${ }^{1}$ Харківський національний педагогічний університет імені Г.С. Сковороди \\ Authors' Contribution: A - Study design; B - Data collection; C - Statistical analysis; D - Manuscript Preparation; E - Funds Collection
}

DOI: $10.17309 / \mathrm{jltm} .2021 .2 .05$

\begin{abstract}
Анотація
Мета дослідження - визначити особливості прояву гендерних відмінностей у швидкісній підготовленості школярів молодших класів, які займаються в секції карате на спортивно-оздоровчому етапі.

Матеріали і методи. У дослідженні прийняли участь дівчатка 7 років $(\mathrm{n}=10), 8$ років $(\mathrm{n}=10), 9$ років $(\mathrm{n}=15), 10$ років $(n=15)$; хлопчики 7 років $(n=10), 8$ років $(n=10), 9$ років $(n=15), 10$ років $(n=15)$. Діти та їхні батьки були інформовані про всі особливості дослідження і дали згоду на участь в експерименті. Для вирішення поставлених завдань були використані методи дослідження: аналіз науково-методичної літератури, педагогічне тестування та методи математичної статистики обробки результатів дослідження.

Результати. За результатами тестування спостерігаються статистично достовірні гендерні розбіжності за показниками тестів: біг 30м з високого старту - $9(\mathrm{p}=0,001), 10(\mathrm{p}=0,013)$ років; стрибок у довжину 3 місця -7 $(\mathrm{p}=0,005), 8$ ( $\mathrm{p}=0,004), 9(\mathrm{p}=0,001), 10(\mathrm{p}=0,015)$ років; човниковий біг $4 \times 9-8(\mathrm{p}=0,009), 9(\mathrm{p}=0,006), 10(\mathrm{p}=0,011)$ років; стрибки зі скакалкою - 10 ( $\mathrm{p=0,049)}$ років; індексу швидкості - 9 ( $\mathrm{p}=0,001)$ років; індекс швидкісної сили - 7 ( $\mathrm{p}=0,001), 9(\mathrm{p}=0,0001), 10(\mathrm{p}=0,03)$ років.
\end{abstract}

Висновки. Встановлено, що відмінності існують, але в кожній віковій групі вони різні. В 7 років діти мало відрізняються за гендерними ознаками, але з віком збільшується кількість структурних елементів швидкісної підготовленості за якими показники дівчат і хлопців статистично різні.

Ключові слова: школярі молодших класів, швидкісна підготовленість, гендерні особливості, кіокушинкай карате.

\section{Вступ}

Велику популярність в суспільстві отримало карате кіокушинкай. Цей вид єдиноборств широко поширюється в нашій країні та визнається як вид спорту, що зареєстрований в Єдиному державному реєстрі України з присвоєнням спортивних розрядів і звань. Багаторічна підготовка юних спортсменів в карате будується у відповідності до загальноприйнятої в теорії та методиці сучасного спорту періодизації у відповідності до вікових особливостей фізичного розвитку. Науковцями (Волков \& Филин, 1983; Платонов, 2004; Сергієнко, 2013) встановлені та науково обгрунтовані етапи багаторічної підготовки спортсменів.

Етап спортивно-оздоровчої спрямованості (6-15 років) охоплює перші роки занять, а також в окремих випадках до 15 років. Тренування вирішують задачу укріплення здоров'я дітей, ліквідації недоліків у рівні їх фізичного розвитку, розвитку рухових здібностей, ви-

(c) Zymohliad, M., \& Marchenko, S., 2021. вчення техніки та мінімум знань про тактику карате. Пріоритетними $є$ різностороння фізична та технічна підготовка - фундамент для поглибленої спеціальної підготовки в ката та куміте. Заняття носять переважно ігровий та ознайомлювальний характер (Kalina \& Jagiello, 2000; Marchenko \& Satdyiev, 2021; Марченко \& Гандимов, 2021).

Етап початкової підготовки (8-12 років) ставить перед спортсменом задачу покращення фізичних кондицій i формування рухового потенціалу з метою успішного засвоєння широкого комплексу технічних прийомів і бойових дій в ката і куміте. Важливо на даному етапі сформувати у юних каратистів мотивацію до цілеспрямованої багаторічної підготовки (Ciocan \& Milon, 2017).

Особлива увага приділяється розвитку швидкісних, швидкісно-силових та координаційних здібностей (Марченко \& Безпалько, 2020; Марченко \& Вердиш, 2021), рухливості у суглобах і гнучкості. У техніко-тактичній підготовці ставиться задача оволодіти варіативністю виконання технічних прийомів і бойових дій та уміння їх використовувати в певних змагальних ситуаціях. 
Відомо, що існує велика кількість дітей, що мають слабкий фізичний розвиток і недостатній рівень фізичної підготовленості, але вони бажають займатися фізичною культурою і спортом (Марченко \& Іванов, 2011; Марченко \& Поручіков, 2011; Михальчук, 2021). Зважаючи на положення, що склалося, ця категорія дітей не має можливості займатися в спортивній школі в основних спортивних групах.

Організація в загальноосвітній школі спортивнооздоровчих груп може допомогти вирішити це завдання і залучити до активного зайняття фізичною культурою і спортом додаткові людські ресурси, які заповнять ряди позитивно орієнтованих груп дітей і підлітків. Діти які не пройшли тестування в спортивні групи початкової підготовки, але мають допуск медичної установи зараховуються в спортивно-оздоровчі групи.

Кіокушинкай карате - вид спорту, який характеризується складною координаційною та швидкісною руховою діяльністю яка представляє собою безперервний ланцюг рішень моторно-психологічних задач (Błaszczyszyn, Szczęsna, Pawlyta, Marszałek \& Karczmit, 2019; Марченко \& Безпалько, 2020; Марченко \& Вердиш, 2021). У зв'язку 3 цим до юних спортсменів пред'являються високі вимоги до рівня інтелектуальних та сенсомоторних здібностей. В поєдинках спортсмен повинен постійно переміщуватися по татамі, виконувати різноманітні вибухові атакуючі, обманні та захисні діі. Швидкісні та швидкісно-силові здібності мають життєво важливе значення для досягнення кращих результатів (Alesi, Bianco, Padulo, Vella, Petrucci, Paoli, Palma, \& Pepi, 2014; Ma \& Qu, 2017; Styriak, Billman, \& Augustovicova, 2020).

Вивчення статевих закономірностей розвитку швидкісних здібностей $є$ актуальною проблемою підготовки юних каратистів. Дана інформація буде корисною у процесі управління фізичним вихованням, а також для розробки ефективних програм фізичної підготовки дітей.

Мета дослідження - визначити особливості прояву гендерних відмінностей у швидкісній підготовленості школярів молодших класів, які займаються в секції карате на спортивно-оздоровчому етапі.

\section{Матеріали і методи}

\section{Учасники дослідження}

У дослідженні прийняли участь дівчатка 7 років $(n=10), 8$ років $(n=10), 9$ років $(n=15), 10$ років $(n=15)$; хлопчики 7 років $(n=10), 8$ років $(n=10), 9$ років $(n=15)$, 10 років $(\mathrm{n}=15)$. Діти та їхні батьки були інформовані про всі особливості дослідження і дали згоду на участь в експерименті.

\section{Організачія дослідження}

Для вирішення поставлених завдань були застосовані такі методи дослідження: аналіз науково-методичної літератури, педагогічне тестування та методи математичної статистики обробки результатів дослідження.

У програму тестування ввійшли загальновідомі тести (Круцевич \& Воробйов, 2005; Сергієнко, 2010; Марченко \& Вердиш, 2021). Тести підбиралися таким чином, щоб всебічно охарактеризувати структуру швидкісної підготовленості дітей:

- швидкість в цілісних рухах - біг 30 метрів 3 високого старту;

- швидкісно-силові здібності - стрибок у довжину 3 місця;

- $\quad$ загальна моторика тіла, стійкість до зміни темпу - човниковий біг $4 \times 9$ метрів;

- $\quad$ латентний час простої рухової реакції - хват падаючої палиці Дітріха;

- частота ненавантаженого руху - стрибки зі скакалкою;

- частота одиночного руху - нанесення на швидкість бокових ударів ногами по ракетках 3 партнером оббігаючи конуси «змійкою»;

- диференційована оцінка руховоїпідготовленості дітей - швидкісний індекс (ШІ), індекс швидкісної сили (ІШС).

\section{Статистичний аналіз}

У дослідженні використовувалася програма - IBM SPSS 26. Обчислювались такі параметри: середнє арифметичне значення величини (X), стандартне квадратичне відхилення, яке характеризує мінливість ознаки (S), t-критерій Стьюдента для незалежних вибірок, U-критерій Манна-Уітні. Гіпотеза про рівність дисперсій для порівнюваних груп визначалась за допомогою критерію Лівіня.

\section{Результати}

Аналіз отриманих показників дає підставу зазначити, що значення індексів швидкості та швидкісної сили як у хлопців, так і у дівчат усіх вікових категорій знаходяться на вище за середній, середньому, нижче за середній та низькому рівнях. Високий рівень нормативної диференційованої оцінки розвитку швидкості відносно довжини тіла не спостерігається.

Хлопці за індексом швидкості знаходяться на вище за середній - 4\% середньому - 36\% нижче за середній $42 \%$ та низькому рівнях - 18\%. У дівчат індекс швидкості знаходяться на середньому - 20\% нижче за середній $56 \%$ та низькому рівнях - 24\%.

За індексом швидкісної сили хлопці знаходяться на вище за середній - 20\% середньому - 40\%, нижче за середній - 28\% та низькому рівнях - 6\%. Високу оцінку 6 \% від загальної кількості хлопців отримали тільки діти вікової категорії 9-10 років. У дівчат індекс швидкісної сили знаходиться на вище за середній - $12 \%$, середньому - 40\%, нижче за середній - 34\% та низькому рівнях - $14 \%$.

Результати оцінки розвитку швидкісних здібностей за індексами дають можливість індивідуального підходу до кожної дитини. На основі отриманих даних виникає можливість корегувати рівень фізичного навантаження, що важливо у побудові процесу фізичної підготовки. Впровадження в практику оцінки рівня фізичної підготовленості за індексами створює позитивні передумови для розробки оптимального рухового режиму.

За результатами тестування зроблений порівняльний аналіз середніх величин за віковими нормами (Тюх, 
2009; Сергієнко, 2010; Марченко \& Вердиш, 2021 та інші). Визначено загальний рівень швидкісної підготовленості дітей 2-4 класів і виявлені гендерні особливості. Результати обстеження швидкісних здібностей подаються в таблиці 1.

Дослідження швидкісної підготовленості показало, що більшість показників тестування мають середній, нижче середнього і низький бали. Найнижчий результат і оцінку мають: дівчата 10 років у «Бігу 30 м з високого старту»; хлопці 9, 10 і дівчата 9 років у «Стрибку в довжину 3 місця»; хлопці 7, 9 років і дівчата 8, 9 років у «Човниковому бігу $4 \times 9$ м». Нижче за середню оцінку мають: за показниками тесту «Біг 30 м з високого старту» хлопці всіх вікових груп і дівчата 7, 9 років; у «Стрибку в довжину 3 місця» хлопці 7 , дівчата 7,10 років; у «Човниковому бігу $4 \times 9$ м» - хлопці 8,10 , дівчата 7,10 років; у тесті «Хват падаючої палиці Дітріха» - хлопці 8; у тесті «Нанесення на швидкість бокових ударів ногами» - хлопці 10 років. Інші показники швидкісної підготовленості учнів мають середній результат.

Такий недостатній рівень швидкісної підготовленості може бути визваний гранично низьким соціально-економічним рівень життя населення країни, недоліками в організації навчального процесу, високим навчальним навантаженням, порушенням режиму життєдіяльності (гіподинамією, хронічним недосипанням, незбалансованим, нераціональним харчуванням). Це може призвести до зниження рівня здоров'я дітей.

Розраховані критерії рівності дисперсій Лівіня (табл. $2,3,4,6)$ указують, що дисперсії в групах не розрізняються (p>0,05), тому правомірне використання t-критерію Стьюдента для незалежних вибірок. Отримані рівні

Таблиця 1. Результати тестування

\begin{tabular}{|c|c|c|c|c|c|c|c|}
\hline \multirow{2}{*}{ Тести } & \multirow{2}{*}{ Вік - } & \multicolumn{3}{|c|}{ Хлопці } & \multicolumn{3}{|c|}{ Дівчата } \\
\hline & & $\mathbf{X}$ & $\mathrm{s}$ & $\mathbf{m}$ & $\mathbf{X}$ & $\mathrm{s}$ & $\mathbf{m}$ \\
\hline \multirow[t]{4}{*}{ Біг 30 м з високого старту, с } & 7 & 7,43 & 35 &, 11 & 7,67 & ,38 &, 12 \\
\hline & 8 & 6,82 &, 53 &, 17 & 7,07 & ,49 &, 15 \\
\hline & 9 & 6,55 &, 53 &, 14 & 7,18 & ,36 & 09 \\
\hline & 10 & 6,42 &, 48 &, 12 & 6,84 & ,36 & 09 \\
\hline \multirow[t]{4}{*}{ Стрибок у довжину з місця, см } & 7 & 115,5 & 9,62 & 3,04 & 100,7 & 10,98 & 3,47 \\
\hline & 8 & 127,0 & 9,71 & 3,07 & 114,2 & 7,64 & 2,41 \\
\hline & 9 & 128,9 & 13,35 & 3,44 & 108,2 & 9,29 & 2,39 \\
\hline & 10 & 131,2 & 16,84 & 4,34 & 117,5 & 11,64 & 3,0 \\
\hline \multirow[t]{4}{*}{ Човниковий біг $4 \times 9$ м, с } & 7 & 14,2 &, 59 & ,186 & 14,38 &, 56 & ,17 \\
\hline & 8 & 13,53 & 85 &, 27 & 14,52 & ,65 & 205 \\
\hline & 9 & 13,17 & ,719 & ,18 & 14,01 & ,816 & ,21 \\
\hline & 10 & 12,84 &, 47 &, 12 & 13,48 &, 77 &, 19 \\
\hline \multirow[t]{4}{*}{ Хват падаючої палиці Дітріха, см } & 7 & 36,1 & 4,75 & 1,5 & 33,6 & 3,77 & 1,19 \\
\hline & 8 & 32,3 & 3,74 & 1,18 & 32,7 & 4,08 & 1,29 \\
\hline & 9 & 26,47 & 4,38 & 1,13 & 28,13 & 3,74 & ,965 \\
\hline & 10 & 24,53 & 4,12 & 1,06 & 27,13 & 3,13 & ,81 \\
\hline \multirow[t]{4}{*}{ Стрибки зі скакалкою, разів } & 7 & 6,8 & 2,09 & ,66 & 9,5 & 3,68 & 1,16 \\
\hline & 8 & 10,7 & 3,26 & 1,03 & 11,4 & 4,32 & 1,36 \\
\hline & 9 & 13,73 & 4,59 & 1,18 & 15,2 & 4,34 & 1,12 \\
\hline & 10 & 52,0 & 14,04 & 3,62 & 62,2 & 13,08 & 3,37 \\
\hline \multirow{4}{*}{$\begin{array}{l}\text { Нанесення на швидкість бокових ударів ногами по ракет- } \\
\text { ках з партнером оббігаючи конуси «змійкою», (Крез) }\end{array}$} & 7 & 1,31 &, 056 &, 017 & 1,34 &, 056 & ,017 \\
\hline & 8 & 1,34 & ,085 & ,027 & 1,35 & ,076 &, 024 \\
\hline & 9 & 1,41 & , 126 & ,032 & 1,40 &, 11 & ,027 \\
\hline & 10 & 1,44 & 095 &, 024 & 1,48 &, 09 &, 023 \\
\hline \multirow[t]{4}{*}{ Індекс швидкості (ІШ) } & 7 & 3,26 & 263 & 083 & 3,13 & ,163 & ,052 \\
\hline & 8 & 3,42 & ,244 & ,077 & 3,22 & ,301 & ,095 \\
\hline & 9 & 3,53 & ,303 & 078 & 3,15 & 155 &, 040 \\
\hline & 10 & 3,23 & ,311 & ,08 & 3,21 & ,192 & ,049 \\
\hline \multirow[t]{4}{*}{ Індекс швидкісної сили (ІШС) } & 7 & ,94 & ,076 & ,024 & ,79 & ,076 & ,024 \\
\hline & 8 & ,93 & ,103 & ,032 & ,86 &, 07 & ,022 \\
\hline & 9 & ,98 & ,094 & ,024 & ,81 &, 074 & ,019 \\
\hline & 10 & ,94 & ,123 &, 031 & ,85 & ,094 &, 024 \\
\hline
\end{tabular}


Таблиця 2. Аналіз особливостей прояву швидкісних здібностей у дівчат і хлопців 7 років

\begin{tabular}{|c|c|c|c|c|c|c|c|c|}
\hline \multicolumn{9}{|c|}{ Критерій для незалежних вибірок } \\
\hline \multirow{3}{*}{ Досліджувані показники } & \multicolumn{3}{|c|}{ Критерій Лівіня } & \multicolumn{5}{|c|}{ t-критерій для рівності середніх } \\
\hline & \multirow[t]{2}{*}{$\mathbf{F}$} & \multirow{2}{*}{$\mathbf{p}$} & \multirow{2}{*}{$\mathbf{t}$} & \multirow{2}{*}{$\mathbf{p}$} & \multirow[t]{2}{*}{$\Delta \mathbf{x}$} & \multirow[t]{2}{*}{$\Delta s$} & \multicolumn{2}{|c|}{$\begin{array}{c}\text { 95\% довірчий інтер- } \\
\text { вал для різниці }\end{array}$} \\
\hline & & & & & & & Нижня & Верхня \\
\hline Біг 30м з високого старту, с & , 149 & ,704 & $-1,463$ & ,161 &,- 24 &, 164 &,- 58 &, 1 \\
\hline Стрибок у довжину з місця, см & 015 & ,903 & 3,205 & 005 & 14,8 & 4,61 & 5,1 & 24,5 \\
\hline Човниковий біг $4 \times 9$ м, с & ,085 & ,774 &,- 701 & ,492 &,- 18 &, 25 &,- 72 & ,36 \\
\hline Хват падаючої палиці Дітріха, см &, 577 & ,457 & 1,303 & ,209 & 2,5 & 1,92 & $-1,53$ & 6,53 \\
\hline Стрибки зі скакалкою, разів & 2,903 & ,106 & $-2,012$ & ,059 & $-2,7$ & 1,34 & $-5,52$ & ,12 \\
\hline $\begin{array}{l}\text { Нанесення на швидкість бокових } \\
\text { ударів ногами, (Крез) }\end{array}$ &, 275 & ,606 & $-1,315$ & ,205 &,- 033 &, 025 &,- 08 & 02 \\
\hline Індекс швидкості, (ІШ) & 2,558 &, 127 & 1,326 & ,201 &, 13 & ,098 &,- 07 & 34 \\
\hline Індекс швидкісної сили, (ІШС) &, 000 & ,984 & 4,112 & ,001 &, 14 & 034 &, 07 & ,21 \\
\hline
\end{tabular}

Передбачаються рівні дисперсії

Таблиця 3. Аналіз особливостей прояву швидкісних здібностей у дівчат і хлопців 8 років

\begin{tabular}{|c|c|c|c|c|c|c|c|c|}
\hline \multicolumn{9}{|c|}{ Критерій для незалежних вибірок } \\
\hline \multirow{3}{*}{ Досліджувані показники } & \multicolumn{3}{|c|}{ Критерій Лівіня } & \multicolumn{5}{|c|}{ t-критерій для рівності середніх } \\
\hline & \multirow[t]{2}{*}{$\mathbf{F}$} & \multirow[t]{2}{*}{$\mathbf{p}$} & \multirow[t]{2}{*}{$\mathbf{t}$} & \multirow[t]{2}{*}{$\mathbf{p}$} & \multirow[t]{2}{*}{$\Delta \mathbf{x}$} & \multirow[t]{2}{*}{$\Delta s$} & \multicolumn{2}{|c|}{$\begin{array}{l}\text { 95\% довірчий інтер- } \\
\text { вал для різниці }\end{array}$} \\
\hline & & & & & & & Нижня & Верхня \\
\hline Біг 30 м з високого старту, с &, 060 & ,809 & $-1,09$ & 290 &,- 25 & 229 &,- 73 & ,23 \\
\hline Стрибок у довжину з місця, см & 1,413 & ,250 & 3,274 & ,004 & 12,8 & 3,91 & 4,58 & 21,01 \\
\hline Човниковий біг $4 \times 9$ м, с & ,733 & ,403 & $-2,921$ & ,009 &,- 99 & ,339 & $-1,7$ &,- 28 \\
\hline Хват падаючої палиці Дітріха, см &, 005 & ,943 &,- 228 & ,822 &,- 4 & 1,752 & $-4,08$ & 3,28 \\
\hline Стрибки зі скакалкою, разів & 1,882 & ,187 &,- 408 & ,688 &,- 7 & 1,714 & $-4,3$ & 2,9 \\
\hline $\begin{array}{l}\text { Нанесення на швидкість бокових } \\
\text { ударів ногами, (Крез) }\end{array}$ &, 119 & ,734 &,- 276 & ,785 &,- 01 &, 0361 &,- 086 &, 07 \\
\hline Індекс швидкості, (ІШ) &, 324 &, 576 & 1,632 &, 120 &, 2 & ,122 &,- 057 & ,46 \\
\hline Індекс швидкісної сили, (ІШС) & 2,377 & ,141 & 1,745 & ,098 &, 069 &, 039 &,- 014 &, 15 \\
\hline
\end{tabular}

Передбачаються рівні дисперсії

значимості емпіричних t-критеріїв демонструють, що між групами хлопців і дівчат 7 років не спостерігаються статистично достовірні відмінності $(\mathrm{p}>0,05)$ у швидкісних здібностях. Гендерні ознаки у дітей цього віку не впливають на рівень швидкості та частоти одиночного руху, темпу кроків, швидкості в цілісних рухах, загальної моторики тіла, стійкості до зміни темпу, латентного часу простої рухової реакції, частоти ненавантаженого руху. Показники тестів, що характеризують перераховані прояви швидкості, не мають статистично достовірної різниці ( $>>0,05)$. Хлопці відрізняються від дівчат статистично достовірно лише за показниками тесту «Стрибок у довжину з місця» $(\mathrm{p}=0,005)$ та у індексі швидкісної сили (IШC) $(\mathrm{p}=0,001)$.

Аналіз особливостей прояву швидкісних здібностей у дітей 8 років свідчить, що статистично достовірні розбіжності за результатами тестування спостерігаються між тестами «Стрибок у довжину 3 місця» $(\mathrm{p}=0,004)$ та «Човниковий біг $4 \times 9$ » $(\mathrm{p}=0,009)$. Це можливо обумовлено тим, що у хлопців 8 років починається перший період розвитку м'язової системи, збільшується не тільки вага м'язів, але й змінюються їх фізико-хімічні властивості, збагачуються іннерваційні відношення. Сила м'язів стає більшою. Приріст сили, пов'язаний з віковими змінами, відбувається деякою мірою незалежно від фізичних навантажень. Здібності до інших проявів швидкості у дівчат і хлопців знаходяться на одному рівні.

Аналіз результатів тестування свідчить, що статистично достовірні розбіжності середніх групових результатів дівчат і хлопців 9 років спостерігаються у тестах наступної спрямованості: «Біг 30 м з високого старту» $(\mathrm{p}=0,001)$, «Стрибок у довжину з місця» $(\mathrm{p}=0,0001)$, «Човниковий біг $4 \times 9$ » $(\mathrm{p}=0,006)$, Індекс швидкісної сили $(\mathrm{p}=0,0001)$. Спостерігається збільшення кількості швидкісних параметрів за якими у статевому аспекті діти мають відмінності.

Розраховані критерії рівності дисперсій Лівіня за «Індексом швидкості» указує, що дисперсії показників індексу швидкості в групах дівчат і хлопців 9 років розрізняються $(\mathrm{p}<0,05)$, тому використання $\mathrm{t}$-критерію Стьюдента для незалежних вибірок не правомірне. В даному випадку необхідно використовувати інший критерій. Ми обрали U-критерій Манна-Уітні (табл. 5). Так як асимптотична значущість $U$ - критерій $0,001<0,05$, то нульова гіпотеза про однаковий розподіл «Індексу швидкості» серед дітей 9 років за статевою ознакою відхиляється. Відмінності між значеннями параметра у вибірках груп дівчат і хлопців достовірні $(\mathrm{p}=0,001)$. 
ISSN 2708-7581 (Online). ISSN-L 2708-7573. Journal of Learning Theory and Methodology. 2021. Volume 2, Number 2

Таблиця 4. Аналіз особливостей прояву швидкісних здібностей у дівчат і хлопців 9 років

\begin{tabular}{|c|c|c|c|c|c|c|c|c|}
\hline \multicolumn{9}{|c|}{ Критерій для незалежних вибірок } \\
\hline \multirow{3}{*}{ Досліджувані показники } & \multicolumn{3}{|c|}{ Критерій Лівіня } & \multicolumn{5}{|c|}{ t-критерій для рівності середніх } \\
\hline & \multirow[t]{2}{*}{$\mathbf{F}$} & \multirow[t]{2}{*}{$\mathbf{p}$} & \multirow[t]{2}{*}{$\mathbf{t}$} & \multirow[t]{2}{*}{$\mathbf{p}$} & \multirow[t]{2}{*}{$\Delta \mathbf{x}$} & \multirow[t]{2}{*}{$\Delta s$} & \multicolumn{2}{|c|}{$\begin{array}{l}\text { 95\% довірчий інтер- } \\
\text { вал для різниці }\end{array}$} \\
\hline & & & & & & & Нижня & Верхня \\
\hline Біг 30 м з високого старту, с & 3,184 & 085 & $-3,824$ & 001 &,- 633 & , 165 &,- 97 &,- 29 \\
\hline Стрибок у довжину з місця, см & 1,376 & 251 & 4,937 & 000 & 20,73 & 4,19 & 12,13 & 29,33 \\
\hline Човниковий біг $4 \times 9$ м, с & ,332 & ,569 & $-2,991$ & ,006 &,- 84 &, 28 & $-1,41$ &,- 26 \\
\hline Хват падаючої палиці Дітріха, см & ,561 & , 460 & $-1,119$ & ,272 & $-1,66$ & 1,48 & $-4,71$ & 1,38 \\
\hline Стрибки зі скакалкою, разів & ,066 & 800 &,- 899 & ,376 & $-1,46$ & 1,63 & $-4,81$ & 1,87 \\
\hline $\begin{array}{l}\text { Нанесення на швидкість бокових } \\
\text { ударів ногами, (Крез) }\end{array}$ & ,387 & ,539 & ,233 & 817 &, 010 &, 042 &,- 077 & ,097 \\
\hline Індекс швидкості, (ІШ) & 5,101 & 032 & 4,318 & 000 & ,38 & ,088 & 199 &, 56 \\
\hline Індекс швидкісної сили, (ІШС) & 1,681 & 205 & 5,264 & 000 & ,164 & 031 &, 10 & ,228 \\
\hline
\end{tabular}

Передбачаються рівні дисперсії

Таблиця 5. Аналіз особливостей «Індексу швидкості» у дівчат і хлопців 9 років

\begin{tabular}{lc}
\hline Зведення U-критерію Манна-Уітні для незалежних вибірок \\
\hline Всього & 30 \\
U Манна-Уітні & 35,50 \\
W Вілкоксона & 155,50 \\
Статистика критерію & 35,50 \\
Стандартна похибка & 23,858 \\
Стандартизована статистика критерію & $-3,227$ \\
Асимптотична значущість (2-сторонній критерій) &, 001 \\
Точна значущість (2-сторонній критерій) &, 001 \\
\hline
\end{tabular}

Статистично достовірні розбіжності за гендерними ознаками у дітей 10 років спостерігаються у тестах: «Біг 30 м 3 високого старту» $(\mathrm{p}=0,013)$, «Стрибок у довжину з місця» $(\mathrm{p}=0,015)$, «Човниковий біг $4 \times 9$ » $(\mathrm{p}=0,011)$, «Стрибки зі скакалкою» ( $\mathrm{p}=0,049)$, «Індекс швидкісної сили» $(\mathrm{p}=0,03)$. У тестах «Хват падаючої палиці Дітріха», «Нанесення на швидкість бокових ударів ногами» та Індексі швидкості не існувало значимих відмінностей (p>0,05). Тобто гендерні ознаки у дітей цього віку не впливають на рівень швидкості та частоти одиночного руху, латентного часу простої рухової реакції.

\section{Дискусія}

Допускалось, що вивчення гендерних особливостей швидкісної підготовленості школярів молодших класів, які займаються в секції кіокушинкай карате на спортивно-оздоровчому етапі, дозволить удосконалити процес фізичного виховання учнів. Дасть можливість індивідуалізувати навчально-виховну роботу з фізичної культури, диференціювати навчальні завдання та шляхи їх використання, нормувати фізичні навантаження та засоби ї регулювання, підібрати методи та прийоми дидактики відповідно до індивідуальних особливостей організму дитини.

Наведені дані доповнюють результати досліджень рівня рухової підготовленості (Марченко \& Поручіков, 2011; Марченко \& Краснокутський, 2016; Ivashchenko, Nosko, Bartik, \& Makanin, 2020 та інші). Підтверджено низький рівень рухової підготовленості (Марченко, 2008; Tюx, 2009; Pavlova, Vynogradskyi, Ripak, Zikrach, \& Borek, 2016 та інші).

Отримані результати співпадають з даними Назаренко, Катенкова \& Анисимовой (2016), Платонова (2018), Марченко \& Коваленко (2020), що розвиток швидкості на етапі початкової підготовки грає значиму

Таблиця 6. Аналіз особливостей прояву швидкісних здібностей у дівчат і хлопців 10 років

\begin{tabular}{|c|c|c|c|c|c|c|c|c|}
\hline \multicolumn{9}{|c|}{ Критерій для незалежних вибірок } \\
\hline \multirow{3}{*}{ Досліджувані показники } & \multicolumn{2}{|c|}{ Критерій Лівіня } & \multicolumn{6}{|c|}{ t-критерій для рівності середніх } \\
\hline & \multirow[t]{2}{*}{$\mathbf{F}$} & \multirow[t]{2}{*}{ p } & \multirow[t]{2}{*}{$\mathbf{t}$} & \multirow[t]{2}{*}{$\mathbf{p}$} & \multirow[t]{2}{*}{$\Delta \mathbf{x}$} & \multirow[t]{2}{*}{$\Delta \mathrm{s}$} & \multicolumn{2}{|c|}{$\begin{array}{c}\text { 95\% довірчий інтер- } \\
\text { вал для різниці }\end{array}$} \\
\hline & & & & & & & Нижня & Верхня \\
\hline Біг 30м з високого старту, с & 2,214 &, 148 & $-2,656$ & ,013 &,- 413 &, 15 &,- 73 &,- 09 \\
\hline Стрибок у довжину з місця, см &, 643 & ,430 & 2,597 & ,015 & 13,73 & 5,29 & 2,9 & 24,56 \\
\hline Човниковий біг $4 \times 9$ м, с & 2,283 &, 142 & $-2,733$ &, 011 &,- 64 &, 234 & $-1,12$ &,- 16 \\
\hline Хват падаючої палиці Дітріха, см & ,663 & ,422 & $-1,944$ &, 062 & $-2,6$ & 1,34 & $-5,33$ &, 14 \\
\hline Стрибки зі скакалкою, разів &, 053 & ,819 & $-2,058$ & ,049 & $-10,2$ & 4,95 & $-20,3$ &,- 05 \\
\hline $\begin{array}{l}\text { Нанесення на швидкість бокових ударів } \\
\text { ногами, (Крез) }\end{array}$ & ,257 &, 616 & $-1,126$ &, 270 &,- 038 &, 034 &,- 11 &, 031 \\
\hline Індекс швидкості, (ІШ) & 2,94 & ,097 &, 212 &, 834 &, 02 & ,09 &,- 17 &, 21 \\
\hline Індекс швидкісної сили, (ІШС) & ,088 & ,769 & 2,281 &, 030 &, 091 &, 04 &, 01 &, 17 \\
\hline
\end{tabular}

Передбачаються рівні дисперсії 
роль в досягненні високого спортивного результату. Що швидкісна підготовка спортсменів є складним процесом диференційованого розвитку елементарних і комплексних видів швидкісних здібностей та їх інтегрального вдосконалення з урахуванням специфіки виду спорту, етапу багаторічної підготовки (Платонов, 2018), особливостей вікового розвитку (Марченко \& Поручіков, 2011) та гендерних особливостей (Марченко, 2007; Єрмаков, Іващенко, \& Хом'яков, 2020; Ivashchenko, Nosko, Bartik, \& Makanin, 2020). На думку багатьох авторів на етапі початкової підготовки значну частину тренувального процесу необхідно приділяти увагу бігу на коротких відрізках, стрибковим вправам, рухливим і спортивним іграм (Марченко \& Голубов, 2015; Назаренко, Катенков, \& Анисимова, 2016; Marchenko \& Satdyiev, 2021 та інші).

Своєю роботою ми прагнули підтвердити знання про важливе значення вивчення гендерних особливостей рухової підготовленості в фізичному вихованні і спорті (Cañadas, Gómez, García-Rubio \& Ibáñez, 2018; Cai, Qiu, Chen, Pan, Shen, \& Kang, 2019; Єрмаков, Іващенко, \& Хом'яков, 2020). Наші дані узгоджуються з результатами отриманими Gao, Zeng, PopeWang, \& Yu, (2019), Herrmann, Heim, \& Seelig, (2019), Ivashchenko, Nosko, Bartik, \& Makanin, (2020), що уже починаючи з молодшого шкільного віку відмічаються гендерні особливості рухової підготовленості. Також підтверджуються висновки Іващенко (2017), що за тестами («Човниковий біг $4 \times 9$ м», «Біг 30 м», «Частота рухів руками», «Хват падаючої палиці Дитріха»), які характеризують прояв швидкості у 7 річних дітей, розбіжності у результатах тестування статистично недостовірні.

\section{Висновки}

Аналіз науково-педагогічної літератури дав змогу виділити етапи спортивно-оздоровчої спрямованості та початкової підготовки, які охоплюють дітей молодшого шкільного віку. Проаналізувати рухові здібності необхідні для занять кіокушинкай карате та виявити важливість швидкості, як однієї з головних складових рухової підготовленості. Вивчити структуру рухової здібності «швидкість». Тренування можуть відбуватися як у ДЮСШ, так і у спортивних секціях на базі загальноосвітньої школи.

Ознайомились 3 методикою організації проведення тестування, виявили найбільш інформативні тести для

\section{Література}

Волков, В.М., \& Филин, В.П. (1983). Спортивньй отбор. М.: Физкультура и спорт, 176.

Платонов, В.Н. (2004). Система подготовки спортсменов в олимпийском спорте (общая теория и ее практические приложения). Киев: Олимпийская литература, 808.

Сергиенко, Л.П. (2013). Спортивный отбор: теория и практика: монография [Текст]. М. : Советский спорт, 1048.

Kalina, R.M., Jagiełło, W. (2000). Zabawowe formy walki w wychowaniu fizycznym i treningu sportowym. Zeszyty Naukowo-Metodyczne. Warszawa : Wydaw. AWF, 68. оцінки рівня спеціальної і загальної швидкісної підготовленості дітей. Діагностика і комплексна оцінка швидкості на етапі відбору і початкової підготовки актуальна. Отримані дані дозволяють не лише дати об'єктивну картину перспективності об'єкту, що вивчається, але і підбирати ефективні засоби і методи реалізації учбово-тренувального процесу що забезпечують збереження здоров'я і позитивний мотиваційний вектор до подальшої спортивної діяльність у фазі поглибленої спортивної спеціалізації.

Середні показники досліджуваних дітей представлені у роботі характеризують рівень прояву в них швидкісних здібностей. Більшість показників тестування мають середній, нижче середнього і низький бали.

За результатами тестування спостерігаються статистично достовірні гендерні розбіжності за показниками тестів:

- біг 30 м $з$ високого старту - $9(\mathrm{p}=0,001), 10$ $(\mathrm{p}=0,013)$ років;

- стрибок у довжину з місця - 7 ( $\mathrm{p}=0,005), 8$ $(\mathrm{p}=0,004), 9(\mathrm{p}=0,001), 10(\mathrm{p}=0,015)$ років;

- човниковий біг $4 \times 9-8$ ( $\mathrm{p}=0,009), 9(\mathrm{p}=0,006), 10$ $(\mathrm{p}=0,011)$ років;

- стрибки зі скакалкою - $10(\mathrm{p}=0,049)$ років;

- індексу швидкості - $9(\mathrm{p}=0,001)$ років;

- індекс швидкісної сили - $7(\mathrm{p}=0,001), 9(\mathrm{p}=0,0001)$, $10(\mathrm{p}=0,03)$ років.

Встановлено, що відмінності існують, але в кожній віковій групі вони різні. В 7 років діти мало відрізняються за гендерними ознаками, але з віком збільшується кількість структурних елементів швидкісної підготовленості за якими показники дівчат і хлопців статистично різні.

\section{Вдячності}

Робота виконана відповідно до плану науково дослідної роботи кафедри теорії і методики фізичного виховання Харківського національного педагогічного університету імені Г.С. Сковороди.

\section{Конфлікт інтересів}

Автори заявляють про відсутність конфлікту інтересів.

\section{References}

Volkov, V.M., \& Filin, V.P. (1983). Sportivnyi otbor. M.: Fizkultura i sport, 176.

Platonov, V.N. (2004). Sistema podgotovki sportsmenov v olimpiiskom sporte (obshchaia teoriia i ee prakticheskie prilozheniia). Kiev: Olimpiiskaia literatura, 808.

Sergienko, L.P. (2013). Sportivnyi otbor: teoriia i praktika: monografiia [Tekst]. M. : Sovetskii sport, 1048.

Kalina, R.M., Jagiełło, W. (2000). Zabawowe formy walki w wychowaniu fizycznym i treningu sportowym. Zeszyty Naukowo-Metodyczne. Warszawa : Wydaw. AWF, 68.

Marchenko, S., \& Satdyiev, B. (2021). Effectiveness of Using Active Games for Strength Development in 10-Year-Old 
Marchenko, S., \& Satdyiev, B. (2021). Effectiveness of Using Active Games for Strength Development in 10-Year-Old Boys at the Initial Training Stage in Kyokushin Karate. Teoriâ ta Metodika Fizičnogo Vihovannâ, 21(1), 84-89. https://doi.org/10.17309/tmfv.2021.1.11

Марченко, С., \& Гандимов, Б. (2021). Розвиток силових здібностей ігровими засобами з елементами одноборств на спортивно-оздоровчому етапі у дівчат 10 років. Журнал теорії та методології навчання, 2(2), 68-74. https://doi.org/10.17309/jltm.2021.2.03

Ciocan, D., \& Milon, A. (2017). Study Regarding the Motives of Children Participation in Sport Activities. LUMEN Proceedings, 1, 159-168. https://doi.org/10.18662/lumproc.rsacvp2017.15

Марченко, С., \& Безпалько, Д. (2020). Контроль і оцінка координаційних здібностей хлопчиків 7 років на етапі початкової підготовки в кіокушинкай карате. Журнал теорії та методологї навчання, 1(2), 82-88. https://doi.org/10.17309/jltm.2020.2.06

Марченко, С., \& Вердиш, Я. (2021). Оцінка надійності та інформативності показників координаційної підготовленості хлопчиків 8 років. Журнал теорії та методології навчання, 2(1), 21-28. https://doi.org/10.17309/jltm.2021.1.03

Марченко, С., \& Іванов, В. (2011). Оцінка фізичного розвитку хлопчиків 6-10 років у контексті сучасних завдань фізичного виховання. Teoriâ ta Metodika Fizičnogo Vihovannâ, (8), 10-13. Retrieved from https:// www.tmfv.com.ua/journal/article/view/730

Марченко, С., \& Поручіков, В. (2011). Оцінка рухової підготовленості хлопчиків молодших класів. Теорія та методика бізичного виховання, (7), 14-17. https://tmfv. com.ua/journal/article/view/723

Михальчук, А.Д. (2021). Диференційована оцінка фізичної підготовленості молодших школярів, віднесених до різних медччних груп в процесі фізичного виховання: автореф. дис. на здобуття наук. ступеня канд. наук 3 фіз. вих. і спорту : 24.00.02. / А.Д. Михальчук. Київ, 22.

Błaszczyszyn, M., Szczęsna, A., Pawlyta, M., Marszałek, M., Karczmit, D. (2019). Kinematic Analysis of Mae-Geri Kicks in Beginner and Advanced Kyokushin Karate Athletes. Int. J. Environ. Res. Public Health, 16(17), 3155. https://doi.org/10.3390/ijerph16173155

Alesi, M., Bianco, A., Padulo, J., Vella, F. P., Petrucci, M., Paoli, A., Palma, A., \& Pepi, A. (2014). Motor and Cognitive Development: The Role of Karate. Muscles, Ligaments and Tendons Journal, 4, 114-120. https://doi.org/10.11138/mltj/2014.4.2.114

Ma, A.W.W., \& Qu, L.H. (2017). Effects of Karate Training on Basic Motor Abilities of Primary School Children. Advances in Physical Education, (7), 130-139. https://doi.org/10.4236/ape.2017.72012

Styriak, R., Billman, M., \& Augustovicova, D. (2020). Karate agility: The new competition category for children's physical development with very high test/re-test reliability. Ido Movement for Culture. Journal of Martial Arts Anthropology, 20(3), 32-37. https://doi.org/10.14589/ido.20.3.5

Круцевич Т.Ю., Воробйов М.И. (2005) Контроль в физическом воспитании детей подростков и юночей. К. : Олімпійська література, 195.
Boys at the Initial Training Stage in Kyokushin Karate. Teoriâ ta Metodika Fizičnogo Vihovannâ, 21(1), 84-89. https://doi.org/10.17309/tmfv.2021.1.11

Marchenko, S., \& Handymov, B. (2021). Development of Strength Abilities Using Play Techniques with Elements of Martial Arts at the Sports and Recreational Stage in 10-Year-Old Girls. Journal of Learning Theory and Methodology, 2(2), 68-74. https://doi.org/10.17309/jltm.2021.2.03

Ciocan, D., \& Milon, A. (2017). Study Regarding the Motives of Children Participation in Sport Activities. LUMEN Proceedings, 1, 159-168. https://doi.org/10.18662/lumproc.rsacvp2017.15

Marchenko, S., \& Bezpalko, D. (2020). Control and Assessment of 7-Year-Old Boys' Coordination Abilities at the Initial Training Stage in Kyokushin Karate. Journal of Learning Theory and Methodology, 1(2), 82-88. https://doi.org/10.17309/jltm.2020.2.06

Marchenko, S., \& Verdysh, Ya. (2021). Assessment of Reliability and Informativeness of Coordination Fitness Indicators of 8-Year-Old Boys. Journal of Learning Theory and Methodology, 2(1), 21-28. https://doi.org/10.17309/jltm.2021.1.03

Marchenko, S., \& Ivanov, V. (2011). Otsinka fizychnoho rozvytku khlopchykiv 6-10 rokiv u konteksti suchasnykh zavdan fizychnoho vykhovannia. Teoriâ ta Metodika Fizičnogo Vihovannâ, (8), 10-13. Retrieved from https://www.tmfv.com.ua/journal/article/view/730

Marchenko, S., \& Poruchikov, V. (2011). Otsinka rukhovoi pidhotovlenosti khlopchykiv molodshykh klasiv. Teoriâ ta Metodika Fizičnogo Vihovannâ, (7), 14-17. https://tmfv.com.ua/journal/article/view/723

Mykhalchuk, A.D. (2021). Dyferentsiiovana otsinka fizychnoi pidhotovlenosti molodshykh shkoliariv, vidnesenykh do riznykh medychnykh hrup $v$ protsesi fizychnoho vykhovannia: avtoref. dys. na zdobuttia nauk. stupenia kand. nauk z fiz. vykh. i sportu : 24.00.02. / A.D. Mykhalchuk. Kyiv, 22.

Błaszczyszyn, M., Szczęsna, A., Pawlyta, M., Marszałek, M., Karczmit, D. (2019). Kinematic Analysis of Mae-Geri Kicks in Beginner and Advanced Kyokushin Karate Athletes. Int. J. Environ. Res. Public Health, 16(17), 3155. https://doi.org/10.3390/ijerph16173155

Alesi, M., Bianco, A., Padulo, J., Vella, F. P., Petrucci, M., Paoli, A., Palma, A., \& Pepi, A. (2014). Motor and Cognitive Development: The Role of Karate. Muscles, Ligaments and Tendons Journal, 4, 114-120. https://doi.org/10.11138/mltj/2014.4.2.114

Ma, A.W.W., \& Qu, L.H. (2017). Effects of Karate Training on Basic Motor Abilities of Primary School Children. Advances in Physical Education, (7), 130-139. https://doi.org/10.4236/ape.2017.72012

Styriak, R., Billman, M., \& Augustovicova, D. (2020). Karate agility: The new competition category for children's physical development with very high test/re-test reliability. Ido Movement for Culture. Journal of Martial Arts Anthropology, 20(3), 32-37. https://doi.org/10.14589/ido.20.3.5

Krutcevich T.Iu., Vorobiov M.I. (2005) Kontrol v fizicheskom vospitanii detei podrostkov i iunoshei. K. : Olimpiiska literatura, 195. 
Сергієнко, Л.П. (2010). Спортивна метрологія : теорія $i$ практичні аспекти. К.: КНТ, 776.

Тюх, I.А. (2009). Індивідуальні норми фізичної підготовленості молодших школярів у процесі бізичного виховання: автореф. дис. на здобуття наук. ступеня канд. наук з фіз. вих. і спорту : 24.00.02. / I.A. Тюх; Нац. УФВіСУ. Київ, 20.

Марченко, С., \& Краснокутський, С. (2016). Характеристика впливу ігрових засобів на динаміку розвитку швидкості у дівчаток молодшого шкільного віку. Теорія та методика фізичного виховання, (4), 2532. https://doi.org/10.17309/tmfv.2016.4.1176

Ivashchenko, O., Nosko, Yu., Bartik, P., \& Makanin, O. (2020). Gender-Related Peculiarities of 7-Year-Old Schoolchildren's Motor Fitness. Teoriâ ta Metodika Fizičnogo Vihovannâ, 20(4), 228-233. https://doi.org/10.17309/tmfv.2020.4.05

Марченко, C.I. (2008). Характеристика впливу ігрових засобів на динаміку розвитку швидкісно-силових здібностей учнів молодшого шкільного віку. Теорія та методика фбізчного виховання, 8(1), 29-34. https://www.tmfv.com.ua/journal/article/view/390

Pavlova, Iu., Vynogradskyi, B., Ripak, I., Zikrach, D., \& Borek, Z. (2016). Prognostication of health-related life quality of Ukrainian residents due to physical activity level. Journal of Physical Education and Sport (JPES), 16(2), Art. 65: 418423. https://doi.org/10.7752/jpes.2016.02065

Назаренко, Л.Д., Катенков, А.Н., Анисимова, Е.А. (2016). Педагогические условия повышения результативности бега на короткие дистанции [Текст]. Педогогическо-психологчческие и медико-биологические проблемы физической культуры и спорта, 1(38). 77-86. https://doi.org/10.14526/01_1111_82

Платонов, В. (2015). Скоростные способности и основы методики их развития. Наука в олимпийском спорте. 15(4). 20-22. http://nbuv.gov.ua/UJRN/NOS_2015_4_4

Марченко, С., \& Коваленко, К. (2020). Оптимізація режиму навчання техніки прямого удару ногою «має гері» в кіокушинкай карате хлопців 10 років. Журнал теорії та методології навчання, 1(1), 33-39. https://doi.org/10.17309/jltm.2020.1.05

Марченко, С. (2007). Особливості рухової підготовленості молодших школярів. Teoriâ ta Metodika Fìzičnogo Vihovannâ, (5), 15-18, 35, 36. Retrieved from https://www. tmfv.com.ua/journal/article/view/307

Єрмаков, С., Іващенко, О., \& Хом'яков, О. (2020). Гендерні особливості рухової підготовленості школярів 8 років. Журнал теорії та методології навчання, 1(2), 75-81. https://doi.org/10.17309/jltm.2020.2.05

Марченко, С., \& Голубов, В. (2015). Особливості впливу ігрових режимів на динаміку розвитку швидкості у хлопчиків молодшого шкільного віку. Теорія та методика фізичного виховання, (4), 17-24. https://doi.org/10.17309/tmfv.2015.4.1152

Cañadas, M., Gómez, M.-A., García-Rubio, J., \& Ibáñez, S. J. (2018). Analysis of Training Plans in Basketball: Gender and Formation Stage Differences. Journal of Human Kinetics, 62(1), 123-134. Scopus. https://doi.org/10.1515/hukin-2017-0164

Cai, G., Qiu, J., Chen, S., Pan, Q., Shen, X., \& Kang, J. (2019). Hematological, Hormonal and Fitness Indices in Youth
Serhiienko, L.P. (2010). Sportyvna metrolohiia : teoriia i praktychni aspekty. K.: KNT, 776.

Tiukh, I.A. (2009). Indyvidualni normy fizychnoi pidhotovlenosti molodshykh shkoliariv u protsesi fizychnoho vykhovannia: avtoref. dys. na zdobuttia nauk. stupenia kand. nauk z fiz. vykh. i sportu : 24.00.02. / I.A. Tiukh; Nats. UFViSU. Kyiv, 20.

Marchenko, S., \& Krasnokutskyi, S. (2016). Kharakterystyka vplyvu ihrovykh zasobiv na dynamiku rozvytku shvydkosti u divchatok molodshoho shkilnoho viku. Teoriâ ta Metodika Fizičnogo Vihovannâ, (4), 25-32. https://doi.org/10.17309/tmfv.2016.4.1176

Ivashchenko, O., Nosko, Yu., Bartik, P., \& Makanin, O. (2020). Gender-Related Peculiarities of 7-Year-Old Schoolchildren's Motor Fitness. Teoriâ ta Metodika Fizičnogo Vihovannâ, 20(4), 228-233. https://doi.org/10.17309/tmfv.2020.4.05

Marchenko, S.I. (2008). Kharakterystyka vplyvu ihrovykh zasobiv na dynamiku rozvytku shvydkisno-sylovykh zdibnostei uchniv molodshoho shkilnoho viku. Teoriâ ta Metodika Fizičnogo Vihovannâ, 8(1), 29-34. https://www.tmfv.com.ua/journal/article/view/390

Pavlova, Iu., Vynogradskyi, B., Ripak, I., Zikrach, D., \& Borek, Z. (2016). Prognostication of health-related life quality of Ukrainian residents due to physical activity level. Journal of Physical Education and Sport (JPES), 16(2), Art. 65: 418423. https://doi.org/10.7752/jpes.2016.02065

Nazarenko, L.D., Katenkov, A.N., Anisimova, E.A. (2016). Pedagogicheskie usloviia povysheniia rezultativnosti bega na korotkie distantcii [Tekst]. Pedogogicheskopsikhologicheskie i mediko-biologicheskie problemy fizicheskoi kultury i sporta, 1(38). 77-86. https://doi.org/10.14526/01_1111_82

Platonov, V. (2015). Skorostnye sposobnosti i osnovy metodiki ikh razvitiia. Nauka v olimpiiskom sporte. 15(4). 20-22. http://nbuv.gov.ua/UJRN/NOS_2015_4_4

Marchenko, S., \& Kovalenko, K. (2020). Optimization of Teaching Boys Aged 10 Mae-Geri (Front Kick) Technique in Kyokushin Karate. Journal of Learning Theory and Methodology, 1(1), 33-39. https://doi.org/10.17309/jltm.2020.1.05

Marchenko, S. (2007). Osoblyvosti rukhovoi pidhotovlenosti molodshykh shkoliariv. Teoriâ ta Metodika Fizičnogo Vihovannâ, (5), 15-18, 35, 36. Retrieved from https://www. tmfv.com.ua/journal/article/view/307

Iermakov, S., Ivashchenko, O., \& Khomiakov, O. (2020). GenderRelated Peculiarities of Motor Fitness of 8-Year-Old Schoolchildren. Journal of Learning Theory and Methodology, 1(2), 75-81. https://doi.org/10.17309/jltm.2020.2.05

Marchenko, S., \& Holubov, V. (2015). Osoblyvosti vplyvu ihrovykh rezhymiv na dynamiku rozvytku shvydkosti $\mathrm{u}$ khlopchykiv molodshoho shkilnoho viku. Teoriâ ta Metodika Fizičnogo Vihovannâ, (4), 17-24. https://doi.org/10.17309/tmfv.2015.4.1152

Cañadas, M., Gómez, M.-A., García-Rubio, J., \& Ibáñez, S. J. (2018). Analysis of Training Plans in Basketball: Gender and Formation Stage Differences. Journal of Human Kinetics, 62(1), 123-134. Scopus. https://doi.org/10.1515/hukin-2017-0164

Cai, G., Qiu, J., Chen, S., Pan, Q., Shen, X., \& Kang, J. (2019). Hematological, Hormonal and Fitness Indices in Youth 
Swimmers: Gender-Related Comparisons. Journal of Human Kinetics, 70(1), 69-80. Scopus. https://doi.org/10.2478/hukin-2019-0027

Gao, Z., Zeng, N., Pope, Z. C., Wang, R., \& Yu, F. (2019). Effects of exergaming on motor skill competence, perceived competence, and physical activity in preschool children. Journal of Sport and Health Science, 8(2), 106-113. Scopus. https://doi.org/10.1016/j.jshs.2018.12.001

Herrmann, C., Heim, C., \& Seelig, H. (2019). Construct and correlates of basic motor competencies in primary schoolaged children. Journal of Sport and Health Science, 8(1), 63-70. Scopus. https://doi.org/10.1016/j.jshs.2017.04.002

Іващенко, О. (2017). Статеві особливості рухової підготовленості дітей 6-10 років. Теорія та методика фізичного виховання, 17(1), 3-15. https://doi.org/10.17309/tmfv.2017.1.1180
Swimmers: Gender-Related Comparisons. Journal of Human Kinetics, 70(1), 69-80. Scopus. https://doi.org/10.2478/hukin-2019-0027

Gao, Z., Zeng, N., Pope, Z. C., Wang, R., \& Yu, F. (2019). Effects of exergaming on motor skill competence, perceived competence, and physical activity in preschool children. Journal of Sport and Health Science, 8(2), 106-113. Scopus. https://doi.org/10.1016/j.jshs.2018.12.001

Herrmann, C., Heim, C., \& Seelig, H. (2019). Construct and correlates of basic motor competencies in primary schoolaged children. Journal of Sport and Health Science, 8(1), 63-70. Scopus. https://doi.org/10.1016/j.jshs.2017.04.002

Ivashchenko, O. (2017). Gender-Specific Peculiarities of Motor Preparedness of Children Aged 6-10. Teorìa Ta Metodika Fìzičnogo Vihovannâ, 17(1), 3-15. https://doi.org/10.17309/tmfv.2017.1.1180

\title{
GENDER PECULIARITIES OF SPEED DEVELOPMENT AT THE SPORTS AND HEALTH STAGE OF TRAINING IN KYOKUSHIN KARATE
}

\author{
Mykola Zymohliad ${ }^{\mathrm{ABCD}}$, Svitlana Marchenko ${ }^{\mathrm{ABCD}}$
}

\author{
${ }^{1}$ H. S. Skovoroda Kharkiv National Pedagogical University \\ Authors' Contribution: A - Study design; B - Data collection; C - Statistical analysis; D - Manuscript Preparation; E - Funds Collection \\ Report. Article: 7 p., 6 tabl., 37 sources.
}

Purpose. To determine the peculiarities of manifestation of gender differences in speed fitness of primary school students attending a karate sports section at the sports and health stage.

Materials and methods. The study participants were girls aged $7(n=10), 8(n=10), 9(n=15), 10(n=15)$; boys aged 7 $(\mathrm{n}=10), 8(\mathrm{n}=10), 9(\mathrm{n}=15), 10(\mathrm{n}=15)$. The children and their parents were informed about all the features of the study and gave their consent to participate in the experiment. To solve the tasks set, the following research methods were used: analysis of scientific and methodological literature, pedagogical testing and methods of mathematical statistics for research results processing.

Results. According to the testing results, there are statistically significant gender differences in the indicators of the following tests: "30 m running from a standing start" - $9(\mathrm{p}=0.001), 10$ $(\mathrm{p}=0.013)$ years; "Standing long jump" $-7(\mathrm{p}=0.005), 8(\mathrm{p}=$ $0.004), 9(\mathrm{p}=0.001), 10(\mathrm{p}=0.015)$ years; “ $4 \times 9$ shuttle run" -8 $(\mathrm{p}=0.009), 9(\mathrm{p}=0.006), 10(\mathrm{p}=0.011)$ years; "Rope jumping" $-10(p=0.049)$ years; speed index $-9(p=0.001)$ years; speed strength index $-7(\mathrm{p}=0.001), 9(\mathrm{p}=0.0001), 10(\mathrm{p}=0.03)$ years.

Conclusions. It was found that differences exist, but they are different in each age group. At the age of 7 , children do not differ much in terms of gender, but with age, there is an increase in the number of structural elements of speed fitness, in which the indicators of girls and boys are statistically different.

Keywords: primary school students, speed fitness, gender peculiarities, Kyokushin Karate.

\section{Information about the authors:}

Zimoglyad Mykola: zimoglyad1990k@gmail.com; https://orcid.org/0000-0001-6496-1175; Department of Theory and Methodology of Physical Education, H. S. Skovoroda Kharkiv National Pedagogical University, Alchevskykh St, 29, Kharkiv, 61002, Ukraine.

Marchenko Svitlana: sport-svet1968@ukr.net; https://orcid.org/0000-0002-1013-9511; Department of Theory and Methodology of Physical Education, H. S. Skovoroda Kharkiv National Pedagogical University, Alchevskykh St, 29, Kharkiv, 61002, Ukraine.

Cite this article as: Zymohliad, M., \& Marchenko, S. (2021). Gender Features of Speed Development at the Sports and Health Stage of Training in Kyokushin Karate. Journal of Learning Theory and Methodology, 2(2), 82-90.

https://doi.org/10.17309/jltm.2021.2.05

Received: 18.04.2021. Accepted: 16.06.2021. Published: 30.06.2021

This work is licensed under a Creative Commons Attribution 4.0 International License (http://creativecommons.org/licenses/by/4.0). 